\title{
Use of Bipolar Radiofrequency in Parenchymal Transection of the Liver, Pancreas and Kidney
}

\author{
Madhava Pai Duncan Spalding Long Jiao Nagy Habib \\ HPB Unit, Department of Surgery and Cancer, Hammersmith Hospital, Imperial College London, London, UK
}

\section{Key Words}

Bipolar radiofrequency $\cdot$ Habib 4X $\cdot$ Laparoscopic resection - Liver resection - Partial nephrectomy • Distal pancreatectomy

\begin{abstract}
Background: Intraoperative blood loss has been shown to be an important factor correlating with increased morbidity and mortality in oncological surgery. Despite technological advances in parenchymal transection devices, bleeding remains the single most important complication. To address this, we designed and developed a bipolar radiofrequency (RF) device, the Habib 4X (Angiodynamics, Inc., Queensbury, N.Y., USA), which was initially used specifically for liver resections. Methods: A search using Medline, Embase and Google ${ }^{\mathrm{TM}}$ Scholar was performed for the period January 2001 to August 2011. The following Mesh terms were used: 'bipolar radiofrequency', 'Habib 4X', 'laparoscopic', 'liver resection', 'partial nephrectomy' and 'distal pancreatectomy'. The references of the studies included were also reviewed. Series from our centre were excluded. Results: There were seven series published, reporting a total of 188 liver resections [113 minor ( $<3$ segments) and 75 major ( $\geq 3$ segments)] assisted by the bipolar RF (Habib 4X) device over this period. The median blood loss reported ranged from 15 to $427 \mathrm{ml}$
\end{abstract}

with a transfusion rate of $0-14 \%$ In addition, five series of partial nephrectomies were also identified, reporting a total of 149 (45 open and 104 laparoscopic) cases. Hilar clamping was not used in any of the cases, and the mean blood loss reported was $100-337 \mathrm{ml}$ whilst the transfusion rate ranged from 0 to $7.1 \%$. There was only one published series of distal pancreatectomies; these were laparoscopic and included 14 patients. Conclusion: This review of bipolar RF-assisted liver resections, partial nephrectomies and distal pancreatectomies reported in the literature to date shows that there are significant advantages in using this device in these types of operation.

Copyright $\odot 2012$ S. Karger AG, Basel

\section{Introduction}

The first successful liver resection was performed in the early 1700s for a traumatic liver injury, but it was not until 1888 that Langenbuch reported the first elective liver resection [1]. The problem of significant blood loss during the liver parenchymal transection phase of the procedure, however, limited further advances. The 'clamp crush' technique, allowing controlled division of liver parenchyma, was subsequently reported in the 1970s [2]. This method enabled surgeons to ligate blood vessels

\section{KARGER}

Fax +4161306 1234 E-Mail karger@karger.ch www.karger.com
(C) 2012 S. Karger AG, Basel

0253-4886/12/0291-0043\$38.00/0

Accessible online at:

www.karger.com/dsu
Prof. Nagy Habib

Hammersmith Hospital, Imperial College London

Du Cane Road, London W12 0NN (UK)

Tel. +442083838574

E-Mail nagy.habib@imperial.ac.uk 
Table 1. Liver resections assisted with bipolar RF device

\begin{tabular}{|c|c|c|c|c|c|c|c|c|c|c|c|}
\hline \multirow[t]{2}{*}{ Reference and year } & \multirow[t]{2}{*}{ Technique } & \multicolumn{4}{|c|}{ Resections } & \multirow{2}{*}{$\begin{array}{l}\text { Collection } \\
\text { abscess }\end{array}$} & \multirow{2}{*}{$\begin{array}{l}\text { Bile } \\
\text { leak }\end{array}$} & \multirow{2}{*}{$\begin{array}{l}\text { Median } \\
\text { blood loss, ml }\end{array}$} & \multirow{2}{*}{$\begin{array}{l}\text { Trans- } \\
\text { fusions }\end{array}$} & \multirow{2}{*}{$\begin{array}{l}\text { ITU/HDU } \\
\text { admission }\end{array}$} & \multirow{2}{*}{$\begin{array}{l}\text { 30-day } \\
\text { mortality }\end{array}$} \\
\hline & & $\mathrm{n}$ & Minor & Major & Pringle & & & & & & \\
\hline Ferko et al. [37], 2006 & $\mathrm{H} 4 \mathrm{X}$ & 33 & 19 & 14 & $14(42)$ & 0 & 0 & NS & $1(3)$ & NS & 0 \\
\hline Zacharoulis et al. [38], 2007 & $\mathrm{H} 4 \mathrm{X}$ & 10 & 8 & 2 & 0 & 0 & 0 & minimal & 0 & 0 & 0 \\
\hline Sandonato et al. [39], 2009 & $\mathrm{H} 4 \mathrm{X}$ & 22 & 22 & 0 & NS & $1(4.5)$ & 0 & $15(0-40)$ & $1(4.5)$ & 0 & 0 \\
\hline Wagman et al. [40], 2009 & $\mathrm{H} 4 \mathrm{X}$ & 76 & 31 & 45 & $20(26)$ & $5(6.5)$ & 0 & $427(10-2,500)$ & $11(14)$ & NS & $2(3)$ \\
\hline Curro et al. [41], 2009 & RF cool tip/H4X & 30 & 16 & 14 & 0 & $1(3)$ & 0 & $30(10-120)$ & 0 & 0 & 0 \\
\hline Taibbi et al. [42], $2011^{\mathrm{a}}$ & $\mathrm{H} 4 \mathrm{X}$ & 27 & 27 & 0 & NS & $1(3.7)$ & 0 & NS & NS & NS & 0 \\
\hline Akyildiz et al. [43], 2011 & Laparoscopic H4X & 12 & 12 & 0 & 0 & 0 & 0 & $89 \pm 77^{b}$ & 0 & 0 & 0 \\
\hline
\end{tabular}

Figures in parentheses indicate percentages or range. H4X = Habib 4X; NS = not specified.

a Includes data from Sandonato et al. [39]. ${ }^{\mathrm{b}}$ Mean.

and bile ducts during parenchymal transection in a controlled fashion, with or without vascular inflow occlusion (Pringle manoeuvre). In more recent years, several further techniques have been described for the transection of liver parenchyma [3-5]. Despite these advances in surgical technique, liver resection still frequently results in significant blood loss with many patients requiring blood transfusion peri- or postoperatively [6-8]. The main problem with all of these methods is that whilst small vessels can be coagulated during transection, larger vessels are often left patent, resulting in considerable blood loss requiring tedious clipping and suturing in order to achieve haemostasis.

Radiofrequency (RF) devices have been used for more than a decade to thermoablate nonresectable hepatic lesions $[9,10]$. We have previously expanded the role of RF to include routine liver resections by using a monopolar RF probe. This allows a plane of coagulative necrosis to be developed along the line of parenchymal transection, with subsequent reduction of blood loss and transfusion [11]. This technique, however, was found to be both time consuming and also carried the risk of skin burns from the grounding pad. To address these problems, we designed and developed a bipolar RF device, the Habib 4X (Angiodynamics, Inc., Queensbury, N.Y., USA). Since its introduction, the device has been used for liver resections, partial nephrectomies and distal pancreatectomies. Here, we present a review of bipolar RF-assisted liver resections, partial nephrectomies and distal pancreatectomies reported in the literature (excluding our centre) with an emphasis on blood loss, blood transfusion and post-operative morbidity and mortality.

\section{Methods}

A search using Medline, Embase and Google ${ }^{\mathrm{TM}}$ Scholar was performed for the period January 2001 to August 2011 using the Mesh terms 'bipolar radiofrequency', 'Habib 4X', 'laparoscopic', 'liver resection', 'partial nephrectomy' and 'distal pancreatectomy'. The 'related articles' function was used to broaden the search in PubMed, and references of the studies included were also reviewed. Series from our centre were excluded. The data were analysed with an emphasis on blood loss, blood transfusion and post-operative morbidity and mortality. In series describing liver resections, we also collected data related to bile leaks, intensive care unit/high dependency unit admission, Pringle's manoeuvre and extent of resection. In series describing partial nephrectomies, specific parameters analysed were hilar clamping, pre- and post-procedure creatinine levels and urinary leaks. In distal pancreatectomies, emphasis was placed on the incidence of pancreatic fistulas.

\section{Results}

\section{Liver}

Seven published series, excluding case reports and series from our centre, have reported a total of 188 liver resections $[113$ minor ( $<3$ segments) and 75 major ( $\geq 3$ segments)] assisted by the bipolar RF (Habib 4X) device over this period. The incidence of post-operative collections requiring intervention ranged from 0 to $6.5 \%$. There were no bile leaks or any episodes of post-operative bleeding. The median blood loss reported ranged from 15 to $427 \mathrm{ml}$ with a transfusion rate of $0-14 \%$ (table 1). In addition to these 7 series, Stavrou et al. [12] have reported a liver trisegmentectomy in a patient with colorectal liver metastases using the Habib 4X. The intraoperative blood loss was $100 \mathrm{ml}$; no blood transfusion was required. The patient developed a collection at the resection margin on 
Table 2. Partial nephrectomies assisted with bipolar RF device

\begin{tabular}{|c|c|c|c|c|c|c|c|c|c|}
\hline Reference and year & Technique & $\begin{array}{l}\text { Resec- } \\
\text { tions }\end{array}$ & $\begin{array}{l}\text { Hilar } \\
\text { clamping }\end{array}$ & $\begin{array}{l}\text { Creatinine } \\
\text { before, } \mathrm{mg} / \mathrm{dl}\end{array}$ & $\begin{array}{l}\text { Creatinine } \\
\text { after, mg/dl }\end{array}$ & $\begin{array}{l}\text { Urinary } \\
\text { leak }\end{array}$ & $\begin{array}{l}\text { Mean blood } \\
\text { loss, } \mathrm{ml}\end{array}$ & $\begin{array}{l}\text { Trans- } \\
\text { fusions }\end{array}$ & $\begin{array}{l}\text { 30-day } \\
\text { mortality }\end{array}$ \\
\hline Andonian et al. [44], 2008 & Laparoscopic H4X & 3 & 0 & 1.3 & 1.4 & 0 & 100 & 0 & 0 \\
\hline White et al. [45], 2008 & $\mathrm{H} 4 \mathrm{X}$ & 45 & 0 & 1.14 & 1.29 & $1(2.2)$ & 133.2 & 0 & 0 \\
\hline Nadler et al. [46], 2009 & Laparoscopic H4X & 16 & 0 & 1.03 & 1.07 & 0 & $125(20-500)^{\mathrm{a}}$ & 0 & 0 \\
\hline Wu et al. [47], 2010 & Laparoscopic H4X & 42 & 0 & 0.99 & 1.15 & $7(16.8)$ & 337 & $3(7.1)$ & 0 \\
\hline Bazzi et al. [48], 2011 & Laparoscopic H4X & 59 & 0 & 1.02 & 1.07 & $3(5)$ & 131.4 & $1(1.7)$ & 0 \\
\hline
\end{tabular}

Figures in parentheses indicate percentages or range.

a Median. ${ }^{\mathrm{b}}$ Includes data from Nadler et al. [46].

day 12 which was successfully drained radiologically to be discharged from hospital on day 21. Dulucq et al. [13] have also reported a redo laparoscopic resection of a recurrent hepatocellular carcinoma (HCC) in an 82-yearold patient with minimal blood loss and good post-operative outcome.

\section{Kidney}

Five published series of partial nephrectomies using the Habib 4X were identified, reporting a total of 149 (45 open and 104 laparoscopic) cases (table 2). Hilar clamping was not used in any of the cases, and there was no significant difference in pre- and post-procedure creatinine. The incidence of urinary leaks ranged from 0 to $16.8 \%$. The mean blood loss reported was $100-337 \mathrm{ml}$, whilst the transfusion rate ranged from 0 to $7.1 \%$. There were no mortalities reported in any of the series.

\section{Pancreas}

The only published series of distal pancreatectomies was laparoscopic; this was performed by transecting the pancreas with a Laparoscopic Habib 4X and included 14 patients. There were no conversions to an open procedure, nor were there any blood transfusions, reoperations, or mortalities. The average length of stay was 4.6 days, and only 1 readmission. A clinically significant fistula occurred in 2 patients (14\%), only one of which required an intervention.

\section{Discussion}

Liver

Indications for liver resection have been continually extended over the past two decades, and currently include performing repeat liver resections for recurrent colorectal liver metastases [14-16] and HCCs [17, 18], along with major hepatectomies for hilar cholangiocarcinomas [19]. Despite improvement in the safety of liver resections, the procedure is still associated with mortalities and postoperative complications, the most common of which are liver insufficiency, bile leaks and collections [20].

Parenchymal preserving segmental resections are known to significantly improve post-operative outcome [8]. The bipolar RF device (Habib 4X)-assisted technique allows the majority of liver resections to be performed non-anatomically, often limited to less than 3 segments, thus preserving normal liver parenchyma and enabling the possibility of future resections in the event of further metastases. This is particularly important in patients with cirrhosis and chemotherapy-associated steatohepatitis. In addition, appropriate parenchymal-sparing resections have been shown to offer the same long-term benefit as classical lobar resections, but with less risk [21, 22].

The series identified have reported a low rate of blood transfusion $(0-14 \%)$ in comparison to the majority of published series using other techniques for liver parenchymal transection. Blood transfusion is known to significantly adversely affect post-operative morbidity in patients undergoing liver resection [20,23] and also adds to the overall cost of the procedure. Resections with minimal blood loss and no transfusion therefore remain the primary objective in hepatobiliary surgery.

\section{Kidney}

The increasing widespread use of computerised tomography has led to a dramatic increase in the number of incidentally discovered renal lesions [24]. Open partial nephrectomy is considered to be the gold standard nephron-sparing treatment for renal cell carcinomas [25]. Published data, however, show that partial nephrectomies are used sparingly, mainly because of their atten- 
dant risk and technical difficulty [26]. Recent Surveillance, Epidemiology and End Results data suggest that partial nephrectomies are performed in only $11.1 \%$.

Laparoscopic partial nephrectomies are usually performed by clamping the ipsilateral renal vessels, following which the tumour is excised and the nephrotomy repaired. This decreases intraoperative haemorrhage and improves access to the renal-collecting system for repair. Even for the most experienced laparoscopic renal surgeons, ischaemic time is $50 \%$ longer than that of open surgery, and hypothermia is rarely performed [27]. New data indicate that even a short interval of warm ischaemia can significantly increase the risk of acute renal failure and chronic renal insufficiency [28]. Margin-free excision of the tumour followed by haemostasis and closure of the collecting system must be performed in $<30 \mathrm{~min}$ to avoid irreversible warm ischaemic renal damage [29]. Hilar clamping was not used in any of the 5 series using the Habib $4 \mathrm{X}$ identified. All reported no significant difference in pre- and post-procedure creatinine, whilst urinary leaks, blood loss and transfusion rates were all low. These data demonstrate that non-ischaemic partial nephrectomies using the Habib $4 \mathrm{X}$ are not only feasible, but have a similar safety profile to established techniques and do not compromise oncological outcomes.

\section{Pancreas}

In both open distal pancreatectomies and laparoscopic distal pancreatectomies (LDP), the pancreatic remnant remains a significant source of morbidity. Rates of pancreatic fistulas range from 16 to $30 \%$, and the rates of those that require intervention range from 7 to $22 \%$ [3034]. If these measures fail, the eventual reoperation rates for LDP are reported to be between 5 and 20\% [30, 32]. These results suggest that postoperative pancreatic fistulas remain problematic after distal pancreatectomies, whether performed as an open procedure or laparoscopically. Previous laparoscopic series have relied heavily on the endoscopic stapler for pancreatic transection [31, 32, $34,35]$. Fronza et al. [36] have recently published the first series of LDPs performed transecting the pancreas with a Laparoscopic Habib 4X, with a pancreatic fistula rate of $14 \%(\mathrm{n}=2 / 14)$.

In conclusion, this review of bipolar RF-assisted liver resections, partial nephrectomies and distal pancreatectomies reported in the literature to date shows that there are significant advantages in using this device in these types of operation.

\section{References}

1 Langenbuch C: Ein Fall von Resecktion eines linksseitigen Schnurlappens der Leber. Berl Klin Wochenschr 1888;25:37.

$\$ 2$ Lin TY: A simplified technique for hepatic resection: the crush method. Ann Surg 1974; 180:285-290

-3 Takayama T, Makuuchi M, Kubota K, Harihara Y, Hui AM, Sano K, Ijichi M, Hasegawa $\mathrm{K}$ : Randomized comparison of ultrasonic vs clamp transection of the liver. Arch Surg 2001;136:922-928

-4 Sakamoto Y, Yamamoto J, Kokudo N, Seki M, Kosuge T, Yamaguchi T, Muto T, Makuuchi M: Bloodless liver resection using the monopolar floating ball plus ligasure diathermy: preliminary results of 16 liver resections. World J Surg 2004;28:166-172.

5 Romano F, Franciosi C, Caprotti R, Uggeri F: Hepatic surgery using the Ligasure vessel sealing system. World J Surg 2005;29:110112.

-6 Cunningham JD, Fong Y, Shriver C, Melendez J, Marx WL, Blumgart LH: One hundred consecutive hepatic resections. Blood loss, transfusion, and operative technique. Arch Surg 1994;129:1050-1056.
7 Melendez JA, Arslan V, Fischer ME, Wuest D, Jarnagin WR, Fong Y, Blumgart LH: Perioperative outcomes of major hepatic resections under low central venous pressure anesthesia: blood loss, blood transfusion, and the risk of postoperative renal dysfunction. J Am Coll Surg 1998;187:620-625.

-8 Jarnagin WR, Gonen M, Fong Y, DeMatteo RP, Ben-Porat L, Little S, Corvera C, Weber $S$, Blumgart LH: Improvement in perioperative outcome after hepatic resection: analysis of 1,803 consecutive cases over the past decade. Ann Surg 2002;236:397-406, discussion 406-407.

-9 Jiao LR, Hansen PD, Havlik R, Mitry RR, Pignatelli M, Habib N: Clinical short-term results of radiofrequency ablation in primary and secondary liver tumors. Am J Surg 1999;177:303-306.

10 Gazelle GS, Goldberg SN, Solbiati L, Livraghi $\mathrm{T}$ : Tumor ablation with radio-frequency energy. Radiology 2000;217:633-646.

11 Weber JC, Navarra G, Jiao LR, Nicholls JP, Jensen SL, Habib NA: New technique for liver resection using heat coagulative necrosis. Ann Surg 2002;236:560-563.
12 Stavrou GA, Tzias Z, von Falck C, Habib N, Oldhafer KJ: Hepatic resection using heat coagulative necrosis. First report of successful trisegmentectomy after hypertrophy induction. Langenbecks Arch Surg 2007;392:95-97.

13 Dulucq JL, Wintringer P, Rashid LM: Virtually bloodless laparoscopic liver resection of recurrent hepatoma with a new laparoscopic sealer device: report of our initial laparoscopic experience. Surg Laparosc Endosc Percutan Tech 2007;17:413-415.

14 Adam R, Bismuth H, Castaing D, Waechter F, Navarro F, Abascal A, Majno P, Engerran L: Repeat hepatectomy for colorectal liver metastases. Ann Surg 1997;225:51-60, discussion 60-62.

15 Minagawa M, Makuuchi M, Torzilli G, Takayama T, Kawasaki S, Kosuge T, Yamamoto J, Imamura $\mathrm{H}$ : Extension of the frontiers of surgical indications in the treatment of liver metastases from colorectal cancer: longterm results. Ann Surg 2000;231:487-499.

16 El-Gendi AM, Khorsandi SE, Pai M, Zacharoulis D, Nicholls JP, Spalding DR, Jiao LR, Habib NA: Repeat hepatic resection using a radiofrequency-assisted technique. Dig Surg 2008;25:293-299. 
-17 Shimada M, Takenaka K, Taguchi K, Fujiwara Y, Gion T, Kajiyama K, Maeda T, Shirabe K, Yanaga K, Sugimachi K: Prognostic factors after repeat hepatectomy for recurrent hepatocellular carcinoma. Ann Surg 1998;227:80-85.

-18 Torzilli G, Makuuchi M, Inoue K, Takayama T, Sakamoto Y, Sugawara Y, Kubota K, Zucchi A: No-mortality liver resection for hepatocellular carcinoma in cirrhotic and noncirrhotic patients: is there a way? A prospective analysis of our approach. Arch Surg 1999;134:984-992.

-19 Nimura Y, Kamiya J, Kondo S, Nagino M, Uesaka K, Oda K, Sano T, Yamamoto H, Hayakawa N: Aggressive preoperative management and extended surgery for hilar cholangiocarcinoma: Nagoya experience. J Hepatobiliary Pancreat Surg 2000;7:155-162.

-20 Cescon M, Vetrone G, Grazi GL, Ramacciato G, Ercolani G, Ravaioli M, Del Gaudio M, Pinna AD: Trends in perioperative outcome after hepatic resection: analysis of 1500 consecutive unselected cases over 20 years. Ann Surg 2009;249:995-1002.

-21 Billingsley KG, Jarnagin WR, Fong Y, Blumgart LH: Segment-oriented hepatic resection in the management of malignant neoplasms of the liver. J Am Coll Surg 1998; 187:471-481.

-22 Fan ST, Lo CM, Liu CL, Lam CM, Yuen WK, Yeung C, Wong J: Hepatectomy for hepatocellular carcinoma: toward zero hospital deaths. Ann Surg 1999;229:322-330.

-23 Ercolani G, Ravaioli M, Grazi GL, Cescon M, Del Gaudio M, Vetrone G, Zanello M, Pinna $\mathrm{AD}$ : Use of vascular clamping in hepatic surgery: lessons learned from 1260 liver resections. Arch Surg 2008;143:380-387, discussion 388 .

-24 Parsons JK, Schoenberg MS, Carter HB: Incidental renal tumors: casting doubt on the efficacy of early intervention. Urology 2001; 57:1013-1015.

25 Novick AC: Laparoscopic and partial nephrectomy. Clin Cancer Res 2004; 10:6322S6327S.

-26 Miller DC, Daignault S, Wolf JS Jr, Hafez KS, Kieran K, Dunn RL, Hollenbeck BK: Hospital characteristics and use of innovative surgical therapies among patients with kidney cancer. Med Care 2008;46:372-379.

$\checkmark 27$ Gill IS, Matin SF, Desai MM, Kaouk JH, Steinberg A, Mascha E, Thornton J, Sherief MH, Strzempkowski B, Novick AC: Comparative analysis of laparoscopic versus open partial nephrectomy for renal tumors in 200 patients. J Urol 2003;170:64-68.
28 Thompson RH, Frank I, Lohse CM, Saad IR, Fergany A, Zincke H, Leibovich BC, Blute ML, Novick AC: The impact of ischemia time during open nephron sparing surgery on solitary kidneys: a multi-institutional study. J Urol 2007;177:471-476.

29 Novick AC: Renal hypothermia: in vivo and ex vivo. Urol Clin North Am 1983;10:637644.

30 Mabrut JY, Fernandez-Cruz L, Azagra JS, Bassi C, Delvaux G, Weerts J, Fabre JM, Boulez J, Baulieux J, Peix JL, Gigot JF: Laparoscopic pancreatic resection: results of a multicenter European study of 127 patients. Surgery 2005;137:597-605.

31 Melotti G, Butturini G, Piccoli M, Casetti L, Bassi C, Mullineris B, Lazzaretti MG, Pederzoli P: Laparoscopic distal pancreatectomy: results on a consecutive series of 58 patients. Ann Surg 2007;246:77-82.

32 Pierce RA, Spitler JA, Hawkins WG, Strasberg SM, Linehan DC, Halpin VJ, Eagon JC, Brunt LM, Frisella MM, Matthews BD: Outcomes analysis of laparoscopic resection of pancreatic neoplasms. Surg Endosc 2007;21: 579-586.

33 Goh BK, Tan YM, Chung YF, Cheow PC, Ong HS, Chan WH, Chow PK, Soo KC, Wong WK, Ooi LL: Critical appraisal of 232 consecutive distal pancreatectomies with emphasis on risk factors, outcome, and management of the postoperative pancreatic fistula: a 21-year experience at a single institution. Arch Surg 2008;143:956-965.

34 Kooby DA, Gillespie T, Bentrem D, Nakeeb A, Schmidt MC, Merchant NB, Parikh AA, Martin RC 2nd, Scoggins CR, Ahmad S, Kim HJ, Park J, Johnston F, Strouch MJ, Menze A, Rymer J, McClaine R, Strasberg SM, Talamonti MS, Staley CA, McMasters KM, Lowy AM, Byrd-Sellers J, Wood WC Hawkins WG: Left-sided pancreatectomy: a multicenter comparison of laparoscopic and open approaches. Ann Surg 2008;248:438446.

35 Bilimoria MM, Cormier JN, Mun Y, Lee JE, Evans DB, Pisters PW: Pancreatic leak after left pancreatectomy is reduced following main pancreatic duct ligation. Br J Surg 2003; 90:190-196.

36 Fronza JS, Bentrem DJ, Baker MS, Talamonti MS, Ujiki MB: Laparoscopic distal pancreatectomy using radiofrequency energy. Am J Surg 2010;199:401-404, discussion 404.

-37 Ferko A, Lesko M, Subrt Z, Melichar B, Hoffman P, Dvorak P, Vacek Z, Liao LR, Habib NA, Koci J, Motycka P: A modified radiofrequency-assisted approach to right hemihepatectomy. Eur J Surg Oncol 2006;32: 1209-1211.
38 Zacharoulis D, Tzovaras G, Rountas C, Poultsidis A, Katsogridakis E, Sioka E, Hatzitheofilou C: Modified radiofrequency-assisted liver resection: a new device. J Surg Oncol 2007;96:254-257.

-39 Sandonato L, Cipolla C, Fulfaro F, Lo Re G, Latteri F, Terranova A, Mastrosimone A, Bova V, Cabibbo G, Latteri MA: Minor hepatic resection using heat coagulative necrosis. Am Surg 2009;75:1213-1219.

40 Wagman LD, Lee B, Castillo E, El-Bayar H, Lai L: Liver resection using a four-prong radiofrequency transection device. Am Surg 2009;75:991-994.

-41 Curro G, Bartolotta M, Barbera A, Jiao L, Habib N, Navarra G: Ultrasound-guided radiofrequency-assisted segmental liver resection: a new technique. Ann Surg 2009;250: 229-233.

42 Taibbi A, Furlan A, Sandonato L, Bova V, Galia M, Marin D, Cabibbo G, Soresi M, Bartolotta TV, Midiri M, Lagalla R, Brancatelli G: Imaging findings of liver resection using a bipolar radiofrequency electrosurgical device-Initial observations. Eur J Radiol 2011, Epub ahead of print.

43 Akyildiz HY, Morris-Stiff G, Aucejo F, Fung J, Berber E: Techniques of radiofrequencyassisted precoagulation in laparoscopic liver resection. Surg Endosc 2011;25:1143-1147.

44 Andonian S, Adebayo A, Okeke Z, Lee BR: Habib laparoscopic bipolar radiofrequency device: a novel way of creating an avascular resection margin in laparoscopic partial nephrectomy. J Laparoendosc Adv Surg Tech A 2008;18:853-856.

45 White WM, Klein FA, Waters WB: Nephron sparing surgery using a bipolar radio frequency resection device. J Urol 2008;180: 2343-2347.

46 Nadler RB, Perry KT, Smith ND: Hybrid laparoscopic and robotic ultrasound-guided radiofrequency ablation-assisted clampless partial nephrectomy. Urology 2009;74:202205.

47 Wu SD, Viprakasit DP, Cashy J, Smith ND, Perry KT, Nadler RB: Radiofrequency ablation-assisted robotic laparoscopic partial nephrectomy without renal hilar vessel clamping versus laparoscopic partial nephrectomy: a comparison of perioperative outcomes. J Endourol 2010;24:385-391.

48 Bazzi WM, Allaf ME, Berkowitz J, Atalah HN, Parekattil S, Derweesh IH: Multicenter experience with nonischemic multiport laparoscopic and laparoendoscopic single-site partial nephrectomy utilizing bipolar radiofrequency ablation coagulator. Diagn Ther Endosc 2011;2011:636537. 